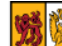 \\ Strenghtening the Evaluation of Evidence in International Criminal Trials \\ McDermott , Yvonne
}

\section{International Criminal Law Review}

DOI:

10.1163/15718123-01704005

Published: 01/07/2017

Peer reviewed version

Cyswllt i'r cyhoeddiad / Link to publication

Dyfyniad o'r fersiwn a gyhoeddwyd / Citation for published version (APA):

McDermott , Y. (2017). Strenghtening the Evaluation of Evidence in International Criminal Trials. International Criminal Law Review, 17(4), 682-702. https://doi.org/10.1163/15718123-01704005

\footnotetext{
Hawliau Cyffredinol / General rights

Copyright and moral rights for the publications made accessible in the public portal are retained by the authors and/or other copyright owners and it is a condition of accessing publications that users recognise and abide by the legal requirements associated with these rights.

- Users may download and print one copy of any publication from the public portal for the purpose of private study or research.

- You may not further distribute the material or use it for any profit-making activity or commercial gain

- You may freely distribute the URL identifying the publication in the public portal ?
}

Take down policy

If you believe that this document breaches copyright please contact us providing details, and we will remove access to the work immediately and investigate your claim. 


\title{
Strengthening the Evaluation of Evidence in International Criminal Trials
}

\begin{abstract}
Recent studies have highlighted instances where findings of fact reached by international criminal tribunals appear not to be adequately supported by the evidence. These works have typically focused on evidential issues, such as witnesses' fading memories, cultural differences in witnesses' re-telling of their experiences that are not appreciated by judges, and more sinister aspects (such as financial incentives offered to witnesses) as the root causes for such discrepancies. However, this article argues that these accounts are incomplete, as they do not recognise difficulties arising from the judicial evaluation of, and reasoning on, the evidential record, which poses potentially insurmountable challenges to reliable fact-finding by international criminal tribunals. This paper examines the analysis of evidence in international criminal trials, and highlights recent differences of opinion between judges on how evidence should be weighed and evaluated. It points to some unique issues arising from the enormity of the fact-finding role in international criminal trials, and the procedural framework embraced by the international criminal tribunals. It discusses alternative tools to assist fact-finding, and their potential applicability to international criminal trials.
\end{abstract}

\section{Keywords}

Evidence; Proof; Fact-finding; ICC; ICTY; ICTR

\section{Introduction}

Findings of fact bear particular importance in international criminal trials. Not only is it the primary purpose of the international criminal trial, as with any trial, to establish the guilt or innocence of the accused; international criminal tribunals carry an additional burden, insofar as their findings are expected to establish 'undisputable findings regarding the atrocities committed', ${ }^{1}$ and thereby to contribute to peace and reconciliation in the affected regions. Given the relatively small number of defendants before international criminal tribunals and the budgetary and personnel resources at their disposal, it is not unreasonable to expect that

\footnotetext{
* The author would like to thank Joanna Nicholson and the organizers and participants of the 'Strengthening the Validity of International Criminal Tribunals' conference in Oslo, August 2016, for very valuable comments on an earlier draft. E-mail: y.mcdermott@bangor.ac.uk.

${ }^{1}$ Daniel David Ntanda Nsereko, 'Foreword' in Karim A. A. Khan, Caroline Buisman and Christopher Gosnell (eds.), Principles of Evidence in International Criminal Justice (Oxford University Press, Oxford, 2010) pp. vvi, v.
} 
their factual findings will be objectively defensible and capable of withstanding rigorous scrutiny.

There has been an explosion of interest in the issue of fact-finding by international criminal tribunals in recent years. As a scholarly endeavour, studies of proof in law have a rich pedigree - they can be traced to at least as far back as John Henry Wigmore's Science of Judicial Proof over a century ago, ${ }^{2}$ through to Jerome Frank's 'fact-scepticism' in the 1930 s, ${ }^{3}$ to the debate about the place of probability in the criminal law between Cohen and others in the 1970s and 1980s, ${ }^{4}$ to more recently, William Twining and others' plea for 'taking facts seriously' 5

\subsection{Taking Facts Seriously in International Criminal Law}

The new evidence scholarship in international criminal law has followed broadly the same trajectory as evidence scholarship in the common law tradition. ${ }^{6}$ Early works focused almost exclusively on rules of admissibility and the move towards liberalisation of those rules. ${ }^{7}$ Then Nancy Combs's book, Fact Finding without Facts, marked a significant turn towards an examination of the proof side of evidence in international criminal trials. ${ }^{8}$

\footnotetext{
2 John Henry Wigmore, The Principles of Judicial Proof as given by Logic, Psychology, and General Experience, and Illustrated in Judicial Trials (Little Brown \& Co., Chicago, 1913).

${ }^{3}$ Jerome Frank, Law and the Modern Mind (Brentano's, New York, 1930), p. xlii.

${ }^{4}$ L. Jonathan Cohen, The Probable and the Provable (Clarendon Press, Oxford, 1977); critiqued in, amongst others, Glanville Williams, 'The Mathematics of Proof - I', Criminal Law Review [1979] 279 and Glanville Williams, 'The Mathematics of Proof - II', Criminal Law Review [1979] 340).

${ }^{5}$ William Twining, 'Taking Facts Seriously' in William Twining, Rethinking Evidence (Cambridge University Press, Cambridge, 2006), p. 14. Twining and his co-authors wanted to incorporate skills training on 'marshalling facts' into professional legal education: Terence Anderson, David Schum and William Twining, Analysis of Evidence ( $2^{\text {nd }}$ edn, Cambridge University Press, Cambridge, 2005), p. xvii.

${ }^{6}$ Paul Roberts, 'The Priority of Procedure and the Neglect of Evidence and Proof: Facing Facts in International Criminal Law', 13(3) J. Int. Crim. Just. (2015) 479-506, p. 481.

${ }^{7}$ Peter Murphy, 'No Free Lunch, No Free Proof: The Indiscriminate Admission of Evidence is a Serious Flaw in International Criminal Trials', 8(2) J. Int. Crim. Just. (2010) 539-573; Steven Kay, 'The Move from Oral Evidence to Written Evidence: 'The Law Is Always Too Short and Too Tight for Growing Humankind', 2(2) $J$. Int. Crim. Just. (2004) 495-502; Eugene O'Sullivan and Deirdre Montgomery, 'The Erosion of the Right to Confrontation under the Cloak of Fairness at the ICTY', 8(2) J. Int. Crim. Just. (2010) 511-538.

${ }^{8}$ Nancy Combs, Fact-Finding Without Facts (Cambridge University Press, Cambridge, 2010).
} 
Combs saw the prevailing assumption at the time as this: even if international criminal trials could not meet some of their more lofty goals of spreading peace and deterring future war criminals - at least they could tell us who did what to whom. ${ }^{9}$ Through a microscopic analysis of witness statements and testimony, Combs revealed serious inconsistencies in such areas as dates, times, distances, and important details, such as who was present at a particular place and time, which challenged that assumption. ${ }^{10}$ Combs identified a number of unique fact-finding impediments faced by international criminal tribunals, namely: the educational attainment of some witnesses, and a failure to comprehend certain concepts as a result; witness intimidation and contempt; communication breakdowns between witnesses and lawyers, caused by linguistic and/or cultural differences, and false testimony. ${ }^{11}$

\subsection{Examining the Evaluation of Evidence}

The identification of these impediments to fact-finding are important, but this article posits that they only tell half the story, insofar as they do not tell us much about the impact of such discrepancies on final judgments. Combs herself argued that 'the testimonial deficiencies plaguing the international tribunals impair their fact-finding competence to such a degree as to render international criminal proceedings a form of show trial', ${ }^{12}$ but her more recent work argues that judges are taking serious inconsistencies in witnesses' accounts more seriously. ${ }^{13}$ Combs also forms the impression from judgments of the International Criminal Tribunal for Rwanda (ICTR) 'that Trial Chambers cast a skeptical eye on the testimony of accomplice witnesses and witnesses who have been imprisoned for genocide crimes. ${ }^{14}$ This impression may be rather optimistic. Taking the Ngirabatware judgment as an example, the Trial Chamber did indeed note that it treated the testimony of witnesses ANAN and ANAT with

\footnotetext{
${ }^{9}$ Ibid., p. 188.

${ }^{10}$ Ibid., pp. 21-43.

${ }^{11}$ Ibid., pp. 63-149.

12 Ibid., p. 172.

${ }^{13}$ Nancy Combs, 'Grave Crimes and Weak Evidence: A Fact-Finding Evolution in International Criminal Law' 38 Harv. Int. L. Rev. (forthcoming, 2016: available online via http://ssrn.com/abstract=2759317), p/ 68.

${ }^{14}$ Ibid., p. 53.
} 
caution, given that they had been convicted of crimes during the genocide. ${ }^{15}$ However, it then went on to base the accused's conviction for incitement at two roadblocks solely based on one or both of these witnesses' testimony (despite there being no corroborating evidence, and despite the existence of testimony from United Nations military observers and others to the contrary). ${ }^{16}$

As the international criminal tribunals established to try those most responsible for atrocities in the former Yugoslavia, Rwanda, and Sierra Leone are winding up or have closed, and the International Criminal Court (ICC) becomes the only permanent international criminal court, the time is ripe to take a wide-reaching view of the judicial evaluation of, and reasoning on, the evidential record in international criminal trials, to determine what lessons can be learned for the conduct of future trials. This article discusses, in Section 2, the approach taken by the international criminal tribunals to the evaluation of evidence to date. Having classified the 'atomistic' and 'holistic' approaches to fact-finding, Section 3 of this article then moves to discuss the main barriers to reliable fact-finding faced by the tribunals. Section 4 presents some models of proof and tools that might potentially be utilized by the tribunals, while Section 5 concludes with a discussion of some of the opportunities that international criminal tribunals can seize upon going forward to strengthen the robustness of their findings of fact, and enhance the legitimacy of their decisions.

\section{Judicial Approaches to the Evaluation of Evidence in International Criminal Tribunals: Divergence and Conflict}

A number of authors have attempted to extract from international criminal judgments some clarity on how judges approach, analyze and synthesize evidence before them. Mark

\footnotetext{
${ }^{15}$ Prosecutor v. Ngirabatware, 20 December 2012, ICTR, Trial Chamber II, Judgment and Sentence, ICTR-9954-T, http://wwww.unictr.org/sites/unictr.org/files/case-documents/ictr-99-54/trial-judgements/en/121220.pdf, accessed 2 November 2016, para. 283.

${ }^{16}$ Ibid, paras 299; 318.
} 
Klamberg posits that they take the following steps: (i) evaluation of a single piece of evidence; (ii) weighing of the totality of the evidence in favour of or against the proposition [of guilt or innocence]; (iii) final determination of whether the combined evidential value is sufficient to establish the proposition. ${ }^{17}$ One might argue that this very reasonable approach is not always evident from the judgments of international criminal tribunals. To the contrary, the manner in which judges evaluate evidence and draw conclusions from that evidence is difficult to derive and appears to be subject to a large degree of discrepancy. As Marjolien Cupido has noted, 'The courts' judgments do not consistently clarify which facts underlie the decisions, what weight is attached to these facts and how this factual evaluation relates to the legal framework of rules, elements, criteria and precedents.' The basis for the weight given to different pieces of evidence is frequently inconsistent and often unpredictable. ${ }^{18}$

This interest in how the tribunals approach the evidence before them is not just academic. Increasingly, dissenting and separate opinions highlight anxiety as to the approach taken by fellow judges to findings of fact. For example, in her dissenting opinion in Šešelj, Judge Lattanzi noted that she 'disagree[d] with the majority of the Chamber on almost everything: the description of the context, the use of the evidence, the flawed or, at best, cursory analysis of the evidence, the disregard for the jurisprudence, and the conclusions. ${ }^{, 19}$ In Karadžić, Judge Baird criticized a finding of the majority that he felt constituted 'speculation run riot'. ${ }^{20}$

\footnotetext{
${ }^{17}$ Mark Klamberg, 'The Alternative Hypothesis Approach, Robustness and International Criminal Justice: A Plea for a "Combined Approach" to Evaluation of Evidence', 13(3) J. Int. Crim. Just. (2015) 535-553, pp. 546547.

${ }^{18}$ Jerome N. Frank, 'A Conflict with Oblivion: Some Observations on the Founders of Legal Pragmatism', 9 Rutgers L. Rev. (1954) 425-463, p. 447, makes a similar general point on when fact-finders exercise discretion over which witness to believe - "The trial court exercises "fact-discretion"... No-one has ever contrived any rules (generalized statements) for making that choice, for exercising that fact-discretion. It therefore lies beyond - is uncaptured by - rules, and it is "unruly". Being unruly, it is usually unpredictable before the lawsuit commences.'

19 Prosecutor v. Šešelj, 31 March 2016, ICTY, Trial Chamber III, Judgement, IT-03-67-T, http://www.icty.org/x/cases/seselj/tjug/en/160331.pdf, accessed 2 November 2016; Partially Dissenting Opinion of Judge Flavia Lattanzi - Amended Version, 31 March 2016, para. 1.

${ }^{20}$ Prosecutor v. Karadžić, 24 March 2016, ICTY, Trial Chamber, Public Redacted Version of Judgement Issued on 24 March 2016, IT-95-5/18-T, http://www.icty.org/x/cases/karadzic/tjug/en/160324_judgement.pdf, accessed 2 November 2016; Dissenting Opinion of Judge Baird, para. 6098.
} 
Similar criticisms arose from the Dissenting Opinion of Judges Trendafilova and Tarfusser in Ngudjolo, where they criticized the evaluation of evidence 'as if it existed in a hermetically sealed compartment'. ${ }^{21}$ In Stanišić and Simatović, the Prosecutor argued that the Trial Chamber erred in its 'compartmentalized assessment [of the evidence], which ... obscured the coherence of the circumstantial evidence adduced by the Prosecution' ${ }^{22}$ The prosecutorial appeal of the acquittals was partially successful, and the case was sent back for a retrial before the Mechanism for the International Criminal Tribunals, some 12 years after the acquitted men were first transferred to the International Criminal Tribunal for the former Yugoslavia (ICTY).

\subsection{Atomism v. Holism in the Judicial Evaluation of Evidence}

From these dissenting and separate opinions, we can determine that there are two broad schools of thought on the evaluation of the evidence. ${ }^{23}$ The first - favoured by the majority in Ngudjolo - prefers a more atomistic approach to the evidence, insofar as it examines each piece of evidence in the context of the evidential record, before forming an opinion on whether the totality of the evidence as a whole supports a conclusion. ${ }^{24}$ The purported danger of this approach is that the judges may be so caught up with the intricacies of whether the evidence supports individual inferences that they lose sight of the bigger picture of the guilt

\footnotetext{
${ }^{21}$ Prosecutor v. Ngudjolo Chui, 7 April 2015, ICC, Appeals Chamber, Judgment on the Prosecutor's Appeal against the Decision of Trial Chamber II entitled 'Judgment Pursuant to Article 74 of the Statute', ICC-01/0402/12, https://www.icc-cpi.int/CourtRecords/CR2015 02537.PDF, accessed 2 November 2016; Joint Dissenting Opinion of Judge Ekaterina Trendafilova and Judge Cuno Tarfusser, para. 46.

${ }^{22}$ Prosecutor v. Stanišić and Simatović, 9 December 2015, ICTY, Appeals Chamber, Judgment, IT-03-69-A, http://www.icty.org/x/cases/stanisic_simatovic/acjug/en/151209-judgement.pdf, accessed 2 November 2016, para. 64.

${ }^{23}$ The main features of the two approaches to the evaluation of evidence - 'atomistic' and 'holistic' - are discussed at length in Michael S. Pardo, 'Juridical Proof, Evidence, and Pragmatic Meaning: Toward Evidentiary Holism’ 95 Nw. U. L. Rev. (2000-2001) 399-442.

${ }^{24}$ Cf. Prosecutor v. Ntagerura, Bagambiki and Imanishimwe, 7 July 2006, ICTR, Appeals Chamber, Judgment, ICTR-99-46-A

http://unictr.unmict.org/sites/unictr.org/files/case-documents/ictr-99-46/trialjudgements/en/060707.pdf, accessed 2 November 2016, para. 174, where three stages for the evaluation of evidence were set out: 1) An assessment of the credibility of the evidence ("This cannot be undertaken by a piecemeal approach'); 2) A determination of whether the evidence presented by the prosecution supports the facts alleged, notwithstanding the defence evidence; 3) An analysis of whether all of the elements of the crimes and mode(s) of liability charged have been proven.
} 
or innocence of the accused..$^{25}$ Indeed, an application of the criminal standard of proof to each item of evidence would constitute an error. ${ }^{26}$

The second approach, by contrast, takes a more holistic view to the evidence as a whole. This approach was favoured by Judges Diarra and Cotte in in Katanga; they argued against 'the approach whereby the probative value of each piece of evidence is evaluated in a fragmentary manner or one which would lead to the application of the beyond reasonable doubt standard to all the facts in the case. ${ }^{27}$

The danger of the holistic approach is that it might be used to 'paper over the cracks', so to speak, or to brush over some specific gaps in the evidence because of the judges' impressionistic feeling that this particular accused is guilty. Such an approach may be suitable in a system where the standard of proof is l'intime conviction du juge, but it is profoundly unsuited to a system of proof beyond reasonable doubt. ${ }^{28}$

An appeal to holism may also result in a less focused prosecution case. To give an example, in Ngirabatware, the ICTR Trial Chamber noted that the Prosecutor had not made specific any submissions on 11 counts of the indictment, and that ' $[\mathrm{u}]$ nder specific circumstances, this may signal that the Prosecution is no longer pursuing a conviction based on allegations contained in the omitted paragraphs, and that it may therefore be unfair to convict the accused on such allegations. ${ }^{29}$ Nevertheless, the Chamber recalled that it specifically asked the Prosecution for its comments on this issue, to which the Prosecution... explained that " $\mathrm{t}] \mathrm{he}$

\footnotetext{
${ }^{25}$ I refute this argument in Yvonne McDermott, 'Inferential Reasoning and Proof in International Criminal Trials', 13(3) J. Int. Crim. Just. (2015) 507-533, p. 528.

${ }^{26}$ Ntagerura, supra note 24, para. 24.

${ }^{27}$ Prosecutor v. Katanga, 7 March 2014, ICC, Trial Chamber II, Jugement rendu en application de l'article 74 du Statut, ICC-01/04-01/07, https://www.icc-cpi.int/CourtRecords/CR2015_04025.PDF, accessed 2 November 2016; Concurring opinion of Judges Fatoumata Diarra and Bruno Cotte, para. 4.

${ }^{28}$ McDermott, supra note 25, p. 528.

${ }^{29}$ Ngirabatware, supra note 15 , para. 18.
} 
trial record speaks for itself", ${ }^{30}$ The Chamber went on to consider the culpability of the accused for those counts on the basis of the evidential record 'as a whole'. This shows that holism allows the prosecution to lay down all of the evidence it has without explicitly linking that evidence to specific charges, and hope that some of it sticks to specific charges - hardly an ideal trial strategy, and one that makes it exceptionally difficult for the accused to defend himself against the charges.

On balance, then, it would appear that both the 'atomistic' approach, which examines each element of the case and the extent to which the evidence supports, or does not support, an inference which the court is asked to draw from that evidence, and the 'holistic' evaluation of the evidence, both have a place in the evaluation of evidence. As Michael Pardo has convincingly argued, a holistic framework should "not eliminate the need for atomistic analysis, but shows that we must see any such analysis as dependent on the evidentiary scheme in which one chooses to analyze the atoms. ${ }^{31}$ Rather than seeing the two approaches as incompatible camps from which the international judge must choose one, we can develop a framework by which individual pieces of evidence, and the inferences that can be drawn therefrom, are subjected to rigorous analysis, whilst not losing sight of the bigger picture of what needs to be proven. Some methods for combining both microscopic analysis and macroscopic marshaling of the evidence are laid out in Part 4 below. It suffices to say at this juncture that a combination of the atomistic and holistic approaches can be achieved individual pieces of evidence can be subjected to searching scrutiny, but this must take place in the context of an analysis of the evidential record as a whole. ${ }^{32}$ This combined approach

\footnotetext{
${ }^{30}$ Ibid., para. 19.

${ }^{31}$ Pardo, supra note 23, pp. 438-439.

32 The Lubanga Appeals Judgment, whilst expressly referring to a holistic approach, actually represents a practical example of this mixed approach: 'The Trial Chamber is required to carry out a holistic evaluation and weighing of all the evidence taken together in relation to the fact at issue': Prosecutor $v$. Lubanga, 1 December 2014, ICC, Appeals Chamber, Judgment on the appeal of Mr Thomas Lubanga Dyilo against his conviction, ICC-01/04-01/06 A5, https://www.icc-cpi.int/CourtRecords/CR2014_09844.PDF, accessed 2 November 2016, para. 20.
} 
would signal a move away from such hollow statements as, 'it does not necessarily follow that because a Trial Chamber did not refer to any particular evidence or testimony in its reasoning, it disregarded it', ${ }^{33}$ which are not uncommon in trial judgments and can give an impression of empty holism, where judgments are based on an overall feeling, rather than a clearly articulated evidential basis.

\subsection{Significance of the Holistic v. Atomistic Schools of Thought}

More generally, the division in approaches to the evaluation of evidence between 'atomistic' and 'holistic' approaches suggests a deep divide amongst international criminal judges as to what exactly the standard of proof requires of them. Of course, the standard of 'proof beyond reasonable doubt' is notoriously difficult to define. Several attempts have been made over the years to come up with a formulation that would best convey the standard to lay jurors, ${ }^{34}$ and indeed it is generally seen as unwise for judges to elaborate on the standard. ${ }^{35}$ However, the deep-seated divide between judges' approaches, as evidenced by the strongly worded dissenting and separate opinions discussed above, highlights the need for an attempt to reconcile the two approaches and to try to find a common ground on the approach to evaluating evidence.

It may have been thought unnecessary, in the early years of the tribunals' operation, for judges to come to an agreed explicit understanding on what the standard of "proof beyond reasonable doubt' actually meant, given that judges in international criminal tribunals are professionals with a great deal of experience. However, it could be argued that, given the great diversity of backgrounds from which international criminal judges hail, there is an even

\footnotetext{
33 Prosecutor v. Musema, 16 November 2001, ICTR, Appeals Chamber, Judgment, ICTR-96-13-A, http://unictr.unmict.org/sites/unictr.org/files/case-documents/ictr-96-13/appeals-chamberjudgements/en/011116.pdf, accessed 2 November 2016, para. 20.

${ }^{34}$ Federico Picinali, 'The Threshold Lies in the Method: Instructing Jurors about Reasoning Beyond Reasonable Doubt' 19(3) Int. J. of Evidence \& Proof (2015) 139-153.

${ }^{35} R$ v. Yap Chuan Ching, (1976) 63 Cr App Rep 7, para. 11.
} 
greater need for an explicit formulation of what the standard of proof actually requires. It seems unlikely, for example, that the majority of judges would agree with the approach taken in the $\breve{S}$ šelj judgment when it found it had not 'receive[d] sufficient evidence to irrefutably establish the existence of a widespread and systematic attack against the civilian population'. ${ }^{36}$ A standard of irrefutable proof appears to be much more stringent than the standard of proof beyond reasonable doubt, and that seems to have been the crucial difference between the majority and Judge Lattanzi, who, in her dissenting judgment, noted:

I can confirm that the Chamber received ample evidence on the widespread and systematic attack... Furthermore, I note that, even though the majority states in the Judgement that the evidence submitted was examined, this evidence is cited only in a disorderly manner in the footnotes, without a real analysis allowing for an understanding of how the majority arrived at such a conclusion. ${ }^{37}$

Judge Lattanzi's dissent highlights the need for a fully reasoned judgment indicating which parts of the evidence led the Chamber to reach its conclusions; this is another area where there is a great deal of divergence between differently-constituted benches. The ICTR Appeals Chamber in Bizimungu helpfully outlined that:

[A] trial chamber should set out in a clear and articulate manner the factual and legal findings on the basis of which it reached the decision to convict or acquit an accused. A reasoned opinion in the trial judgment is essential to ensuring that the Tribunal's adjudications are fair, and, inter alia, allows for a meaningful exercise of the right of appeal by the parties, and enables the Appeals Chamber to understand and review the trial chamber's findings. ${ }^{38}$

Yet, it is clear that some judgments continue to fail in fully articulating the basis of their factual and legal findings; indeed, in Bizimungu, the Appeals Chamber found that the Trial

\footnotetext{
36 Šešelj, supra note 19, para. 192 (emphasis added).

${ }^{37}$ Ibid., Partially Dissenting Opinion of Judge Flavia Lattanzi - Amended Version, para. 11.

38 Prosecutor v. Bizimungu, 30 June 2014, ICTR, Appeals Chamber, Judgment, ICTR-00-56B-A, http://unictr.unmict.org/sites/unictr.org/files/case-documents/ictr-00-56/appeals-chamberjudgements/en/140630.pdf, accessed 2 November 2016, paras. 18-19.
} 
Chamber had 'failed to even attempt to address ... whether the evidence adduced was sufficient to prove Bizimungu's individual criminal responsibility' ${ }^{39}$

A further point of note on the degree of judicial diversity as to approaches to evaluation of the evidence is that it does not appear to be attributable to the judge's own background or the legal system from which they hail. It is notable that Judge van den Wyngaert, from Belgium (a civil law system) was criticized for her atomistic approach to the evidence in Katanga, ${ }^{40}$ while Judges Tarfusser and Trendafilova (from Italy and Bulgaria, both broadly civil law systems) clearly preferred a more holistic approach. ${ }^{41}$

\section{Barriers to Reliable Fact-Finding in International Criminal Trials}

Aside from the difficulties mentioned by Combs, above, relating to the difficulties in obtaining reliable evidence, some other barriers to fact-finding are worthy of further analysis. These are: the volume of the evidential record; the procedural confusion that persists as regards the Trial Chamber's truth-seeking role, and issues surrounding judicial collegiality.

\subsection{Volume of Evidence}

The sheer enormity of the evidential record in most international criminal trials is difficult to comprehend. Keynes's idea of 'weight' has as its main premise that the introduction of further evidence may sometimes decrease the probability of a proposition, but will always increase its weight. ${ }^{42}$ In international criminal trials, it is simply impossible to consider all of the relevant evidence available on the events under consideration, given the scope of international crimes. The evidential record of some cases already stretches to over $1,000,000$

\footnotetext{
${ }^{39}$ Ibid., para. 19.

${ }^{40}$ Katanga, supra note 27, Concurring opinion of Judges Fatoumata Diarra and Bruno Cotte, para. 4.

41 Ngudjolo, supra note 21, Joint Dissenting Opinion of Judge Ekaterina Trendafilova and Judge Cuno Tarfusser.

42 John Maynard Keynes, A Treatise on Probability (Macmillan, London, 1921), pp. 71-77. Because the term 'weight' can be confusing in this context, others have proposed alternative terms, such as the 'quantum' or 'robustness' of the evidence: Ho Hock Lai, A Philosophy of Evidence Law (Oxford University Press, Oxford, 2008), p. 167; Mark Klamberg, Evidence in International Criminal Trials: Confronting Legal Gaps and the Reconstruction of Disputed Events (Martinus Nijhoff, The Hague, 2013), pp. 154-156.
} 
pages, ${ }^{43}$ and even those cases that are limited in scope - such as that of Lubanga, charging the accused with the sole crime of recruiting child soldiers - present enormous evidential records. ${ }^{44}$ For judges to receive, process, and analyse these huge evidential records, and bear all of the relevant pieces of evidence in mind when reaching findings of fact, is clearly an incredibly onerous task.

Simon De Smet has argued that one way for international criminal courts to strengthen their factual findings would be to receive more evidence, but that this would only be feasible if they out-sourced or delegated part of their fact-finding task, perhaps using one of the formal models of proof outlined in Part 4 of this article below. ${ }^{45}$ However, it could be argued that a great deal of outsourcing of the tribunals' fact-finding role already goes on, through the extensive use of the doctrine of judicial notice, particularly at the ad hoc tribunals. The doctrine, as used by the tribunals allows judicial notice to be taken, not just of facts of common knowledge, but also of adjudicated facts from other cases. ${ }^{46}$ In Karadžić, a number of the Trial Chamber's conclusions were based entirely on facts that were judicially noticed from earlier trials. ${ }^{47}$ Again, there is a great deal of diversity amongst Chambers in their approach to this issue; this approach can be contrasted with that taken by a differentlyconstituted ICTY Trial Chamber in Šešelj, which found that: 'The independent nature of the proceedings and the relativity of the adjudicated matter do not allow a Trial Chamber to rely on the legal or factual findings of another Chamber and extend those findings to its own

\footnotetext{
43 Prosecutor v. Prlić et al., 29 May 2013, ICTY, Trial Chamber III, Judgment, IT-04-74-T, http://www.icty.org/x/cases/prlic/tjug/en/130529-1.pdf, accessed 2 November 2016, Annex 2, 'Procedural History'.

${ }^{44}$ The Lubanga Trial Chamber heard 67 witnesses and received 1,373 items of documentary evidence over the six years of the trial.

${ }^{45}$ Simon De Smet, 'Communicating about Probative Value of Evidence and the 'Strength' of Factual Findings (in the Context of International Criminal Proceedings)', paper presented at ICAIL 2015 Workshop, Studying Evidence in the Law: Formal, Computational and Philosophical Methods, June 2015, https://icail2015evidence.files.wordpress.com/2015/01/desmet.pdf, accessed 2 November 2016.

${ }^{46}$ See further, Yvonne McDermott, Fairness in International Criminal Trials (Oxford University Press, Oxford, 2016), pp. 44-46.

${ }^{47}$ Karadžić, supra note 21, paras. 874, 913, 1778.
} 
case. ${ }^{48}$ A degree of clarity and consistency on the question of judicial notice and its proper uses would be welcome.

\subsection{Procedural frameworks of the tribunals and lack of clarity on evaluation of evidence}

The second barrier to reliable fact-finding in international criminal trials is the confusion surrounding the procedural framework of the tribunals. Uncertainty still abounds about the proper boundaries of the judicial role and the place of judicial intervention at trial. As Rosemary Byrne's research has shown, some judges and benches are extremely interventionist while others do not intervene in the questioning of witnesses or the conduct of proceedings at all. ${ }^{49}$

International criminal tribunals are often referred to as representing a sui generis or mixed procedural model. However, the ICC's procedural framework highlights this lack of clarity the Prosecutor has an obligation under the Statute to 'investigate incriminating and exonerating circumstances equally, ${ }^{50}$ This is most similar, broadly speaking, to an inquisitorial legal tradition. However, at trial, the procedure is clearly adversarial, or party based. Unlike in inquisitorial systems, the ICC Prosecutor is not required to create a dossier of evidence; rather, the rules of disclosure that come from adversarial systems apply, and the trial is structured as an 'argument' between Prosecution and Defence (with additional input from participating victims), so the presentation of evidence remains entirely party-driven or adversarial. ${ }^{51}$ There is nothing wrong, in principle, with international courts adopting a mixed procedural model, but as Mirjan Damaška has pointed out, choosing a procedural model 'is not like shopping in a boutique' - one cannot simply pick the elements one likes and discard

\footnotetext{
48 Šě́elj, supra note 19, para. 190.

${ }^{49}$ Rosemary Byrne, 'The New Public International Lawyer and the Hidden Art of International Criminal Trial Practice' 25 Conn. J. Int. L. (2010) 243-303.

${ }^{50}$ Article 54(1)(a), ICC Statute.

${ }^{51}$ Goran Sluiter, 'Procedural Lawmaking' in Shane Darcy and Joseph Powderly (eds.), Judicial Creativity at the International Criminal Tribunals (Oxford University Press, Oxford, 2010), 315-331, 320.
} 
those that one does not like, because each of those elements forms part of a finely-tuned interrelated system. ${ }^{52}$ Without the creation of a dossier or any form of judicial oversight, the obligation becomes essentially meaningless, and relies entirely on us putting a great deal of trust in the Prosecutor. Early experiences in the Lubanga case showed that the disclosure of exculpatory materials by the prosecution cannot always be guaranteed. ${ }^{53} \mathrm{We}$ could also point to diversity in evidential rules - such as a preference for oral testimony, combined with an extensive set of (recently-added ${ }^{54}$ ) rules on the admission of affidavit testimony that precisely undermine that preference, as further evidence of the confused procedural model at the ICC and elsewhere.

\subsection{Collegiality}

As divergences of opinion in the dissenting opinions mentioned above have shown, the collegiate nature of decision-making appears to pose some unique challenges when judges differ on the weight to be given to particular piece of evidence, or on the ultimate reading of whether the evidence leads to a conclusion of guilt beyond reasonable doubt. ${ }^{55}$ John Jackson and Sean Doran, in their study of the Diplock trials in Northern Ireland, noted judicial resistance collective decision-making, with one judge interviewed noting that 'no-one can help the judge on this fact-finding responsibility’. ${ }^{56}$ This resistance may be more pronounced in international criminal tribunals, where judges come from a great diversity of backgrounds; some may have been criminal court judges in their own legal system, whilst others may have

\footnotetext{
52 Mirjan R. Damaška, 'Epistemology and Legal Regulation of Proof' 2 Law, Probability and Risk (2003) 117130, 121.

${ }^{53}$ Prosecutor v. Lubanga, 13 June 2008, ICC, Trial Chamber I, Decision on the consequences of non-disclosure of exculpatory materials covered by Article 54(3)(e) agreements and the application to stay the prosecution of the accused, together with certain other issues raised at the Status Conference on 10 June 2008, ICC-01/0401/06, https://www.icc-cpi.int/CourtRecords/CR2008 03428.PDF, accessed 2 November 2016, paras 77-89.

${ }^{54}$ Resolution ICC-ASP/12/Res.7, adopted 12 November 2013 (amending Rule 68 of the ICC Rules of Procedure and Evidence).

${ }^{55}$ On the importance of collegiality, see Hemi Mistry, 'Collegiality at the International Criminal Court: Lessons from Other International Courts?', in this issue.

56 John Jackson and Sean Doran, Judge without Jury: Diplock Trials in the Adversary System (Oxford University Press, Oxford, 1995), 213.
} 
been diplomats or international law professors and their appointment to the international court may represent the first criminal trial they have sat in judgment of. ${ }^{57}$ That is not to suggest that the judges from criminal law backgrounds are necessarily more suitable for the role - some of international criminal law's finest judges have come from non-judicial backgrounds - but rather that judges who are used to sitting in judgment alone in their own legal systems may find it difficult to defer to their colleagues and engage in joint decisionmaking.

In addition, we have to bear in mind that, on occasion, given the length of trials (and owing to non-re-election to the Tribunal, or dismissal on the grounds of bias, or illness or death) the panel of judges at the start of trial differs by the end of trial, so those that have to weigh up the evidence as a whole may not have been there when the evidence was presented. In $\breve{S}$ šelj, after the close of trial (which lasted almost five years), Judge Harhoff was disqualified from the case and replaced with Judge Niang who was initially given six months to familiarise himself with the trial record as a whole. ${ }^{58}$ In her dissent, Judge Lattanzi noted that Judge Niang, having not been present at the hearings, was probably unaware of a climate of intimidation that pervaded the trial.

\section{Models of Proof and Tools to Assist in Fact-Finding}

\footnotetext{
57 Article 36(3)(b) of the ICC Statute requires that judges have established competence in either criminal law and procedure or have established competence in relevant areas of international law. See further, Gideon Boas, James L. Bischoff, Natalie L. Reid, B. Don Taylor III, International Criminal Law Practitioner Library, Volume III: International Criminal Procedure (Cambridge University Press, Cambridge, 2011), pp. 253-255; Michael Bohlander, 'The International Criminal Judiciary: Problems of Judicial Selection, Independence and Ethics' in Michael Bohlander (ed.), International Criminal Justice: A Critical Analysis of Institutions and Procedures (New York: Cameron May, 2007) pp. 325-390.

${ }^{58}$ Prosecutor v. Šešelj, 28 August 2013, ICTY, Chamber Convened by Order of the Vice-President, Decision on Defence Motion for Disqualification of Judge Frederik Harhoff and Report to the Vice-President, IT-03-67-T, http://www.icty.org/x/cases/seselj/tdec/en/130828.pdf, accessed 2 November 2016; Prosecutor v. Šešelj, 31 October 2013, ICTY, President, Order Assigning a Judge Pursuant to Rule 15, IT-03-67-T, http://www.icty.org/X/cases/seselj/presord/en/131031.pdf, accessed 2 November 2016.
} 
Broadly speaking, there are two major theories on how individuals base their decisions on evidence. The first, called the 'meter model' by Hastie, is based on the premise that the decision-maker starts with a belief, and those beliefs are updated as the trial goes along. ${ }^{59}$ Lon Fuller, noting an American Bar Association statement, outlined the psychological background of this theory:

What generally occurs in practice is that at some early point a familiar pattern will seem to emerge from the evidence; an accustomed label is waiting for the case and, without waiting further proofs, this label is promptly assigned to it. It is a mistake to suppose that this premature cataloguing must necessarily result from impatience, prejudice or mental sloth. Often it proceeds from a very understandable desire to bring the hearing into some order and coherence, for without some tentative theory of the case there is no standard of relevance by which testimony may be measured. ${ }^{60}$

On the other hand, the 'story model' ${ }^{61}$ or 'narrative theory' of proof, the decision-maker is most influenced by the most coherent narrative that fits the evidence presented. In Nsengimana, for example, the ICTR referred to the 'competing narratives' on the evidence that had been presented to the Chamber. ${ }^{62}$ These two approaches - the meter model and the story model - are important to bear in mind when discussing potential methods or tools to assist in judicial decision-making.

\subsection{Bayes Nets}

The first, the Bayesian Network, is most closely linked to the 'meter model'. Bayes Nets, as they are known, are graphical models of the probabilistic relationships between hypotheses and pieces of evidence. Bayes Nets have their origins in a theorem developed by the Reverend Thomas Bayes in the $18^{\text {th }}$ century. Bayes' theorem enables the calculation of the

\footnotetext{
${ }^{59}$ Lola Lopes, 'Two Conceptions of the Juror' in Reid Hastie (ed.) Inside the Juror (Cambridge: CUP, 2003) 255.

${ }^{60}$ Lon L. Fuller, 'The Adversary System' in Harold J. Berman (ed.) The Adversary System: Talks on American Law (Vintage Books, New York, 1961) 30-43.

${ }^{61}$ Nancy Pennington and Reid Hastie, 'The Story Model for Juror Decision-Making' in Reid Hastie (ed.) Inside the Juror (Cambridge University Press, Cambridge, 2003) 192-224.

62 Prosecutor v. Nsengimana, 17 November 2009, ICTR, Trial Chamber I, Judgment, ICTR-01-69-T, http://unictr.unmict.org/sites/unictr.org/files/case-documents/ictr-01-69/trial-judgements/en/091117.pdf, accessed 2 November 2016, paras. 221; 439; 667.
} 
revised odds in favour of a proposition, usually associated with the prosecution, in comparison with an alternative proposition, usually associated with the defence, when evidence relevant to the truth or otherwise of the propositions, is taken into account. The application of Bayes' theorem relies on the individual decision-maker quantifying prior probabilities based on their own intuition. ${ }^{63}$ Thus, 'any resulting inferences of probative value extracted from Bayes nets can only be as good, or as bad, as the initial human inputs. ${ }^{64}$ The decision-maker's prior beliefs are updated as new evidence is presented, in accordance with the probability of that particular piece of evidence. The application of Bayes' Theorem, therefore, encourages fact-finders to interrogate the strength of their own confidence in the truth of a proposition. By today, free software is available to assist in the creation of Bayes Nets, which makes the calculation of revised probabilities much less onerous than any manual attempt to do so. ${ }^{65}$

By committing to estimates of uncertainty for each piece of evidence as part of the reasoning process, the exercise of creating a Bayes Net forces the decision-maker to confront the strength of their confidence in their conclusions. Moreover, an understanding of basic rules of probability may avoid judges falling into some common errors in reasoning, such as finding that they are more certain of one finding than they are of its component parts. ${ }^{66} \mathrm{We}$ can see such an error in reasoning in Gbagbo, where the Prosecutor argued that the Trial Chamber erred in finding that 'each incident underlying the contextual elements of crimes against

\footnotetext{
${ }^{63}$ Paul Roberts and Colin Aitken, The Logic of Forensic Proof: Inferential Reasoning in Criminal Evidence and Forensic Science Guidance for Judges, Lawyers, Forensic Scientists and Expert Witnesses, Royal Statistical Society Practitioner Guide No. 3 (2014), available online at http://www.rss.org.uk/statsandlaw, accessed 2 November 2016, p. 104.

${ }^{64}$ Ibid.

${ }^{65}$ For an example of a practical application of Bayesian probability to international criminal trials, see Yvonne McDermott and Colin Aitken, 'Analysis of Evidence in International Criminal Trials Using Bayesian Belief Networks' (working paper; on file with author).

66 Prosecutor v. Gbagbo, 3 June 2013, ICC, Pre-Trial Chamber I, Decision adjourning the hearing on the confirmation of charges pursuant to article 61(7)(c)(i) of the Rome Statute, ICC-02/11-01/11, https://www.icccpi.int/CourtRecords/CR2015_04878.PDF, accessed 2 November 2016; Office of the Prosecutor, 'OTP Statement on Confirmation of Charges hearing in Laurent Gbagbo case', 11 June 2013, https://www.icccpi.int/iccdocs/PIDS/wu/ED175_ENG.pdf, accessed 2 November 2016.
} 
humanity must be established to the standard of proof enshrined in Article 61(7) of the Statute'. In other words, even if it could not prove that there were substantial grounds to believe that each individual incident making up the widespread attack actually occurred, all of these incidents could be taken together to determine that there were substantial grounds to believe that a widespread attack had indeed occurred. This approach ignores a basic rule of probability which states that the probability of two events occurring together is always less than or equal to the probability of one of those events occurring alone. ${ }^{67}$ Nevertheless, a different majority of the Pre-Trial Chamber later appeared to agree with this approach. ${ }^{68}$

\subsection{Wigmorean analysis}

Another method that might assist in case preparation and in decision making on mixed masses of evidence is Wigmorean analysis. ${ }^{69}$ Wigmorean analysis is a means for structuring, and graphically representing, facts, evidence, and inter-relationships among pieces of evidence. The method assists the chart-maker in structuring arguments and linking those arguments to evidence by requiring him or her to, first, formulate a 'key list' of all the relevant inferences in a case or part of a case, and the evidence that could be adduced to support or disprove from those inferences, and second, draw a chart that links all relevant inferences and evidence to the 'ultimate probandum' (the issue that must ultimately be proven). Thus, the approach is both macroscopic - identifying the relevant propositions that must be drawn to reach an ultimate conclusion on the guilt or innocence of the accused - and microscopic, insofar as it subjects all of the relevant evidence to scrutiny, to determine whether it supports an inference leading to that ultimate probandum.

\footnotetext{
${ }^{67}$ Amos Tversky and Daniel Kahneman, 'Extensional Versus Intuitive Reasoning: The Conjunction Fallacy in Probability Judgment', 90(4) Psychological Review (1983) 293-315.

${ }^{68}$ Prosecutor v. Gbagbo, 12 June 2014, ICC, Pre-Trial Chamber I, Decision on the Confirmation of Charges against Laurent Gbagbo, ICC-02/11-01/11, https://www.icc-cpi.int/CourtRecords/CR2015 04777.PDF, accessed 2 November 2016.

69 Based on Wigmore, supra note 2. The arguments on the potentials of Wigmorean Analysis are expanded further in McDermott, supra note 25.
} 
One key benefit of Wigmorean analysis is that it also incorporates generalisations or beliefs inherent in the decision-maker. Anderson and Twining refer to the decision-maker's 'stock of knowledge' that is drawn from in decision-making. ${ }^{70} \mathrm{We}$ might question to what extent those generalisations can transfer to such the different societies that international judges encounter in their judicial role. Yet, it is clear that judges do draw upon generalisations in deciding on the credibility of witnesses, or the coherence of evidence. In Gatete, for example, the Chamber noted that it had concerns on the merits of a witness's evidence, because it was 'not not convinced that she would have moved to only metres away from the Accused at the roadblock when Interahamwe, who according to her testimony had killed persons with "bladed weapons", were present'. ${ }^{71}$ With respect, how anyone should 'normally' behave in the presence of machete-wielding génocidaires is something that most of us, including the international judge, can only imagine.

\subsection{Utilising Bayes Nets and Wigmorean Analysis in International Criminal Trials}

Refined versions of Wigmorean Analysis and Bayes Nets can both be utilized in a condensed form by focusing such methods on so-called 'jugular facts' in the case. The drafter of the chart or Network can use the method or methods to conduct a microscopic analysis of one crucial element of the case. Judgments show that conviction or acquittal frequently turn on one crucial element, such as whether the accused knew or had reason to know of the acts of his subordinates ${ }^{72}$ or their presence at a particular place at a particular time. ${ }^{73}$

\footnotetext{
${ }^{70}$ Anderson and Twining, supra note 5, p. 275.

${ }^{71}$ Prosecutor v. Gatete, 31 March 2011, ICTR Trial Chamber III, Judgment and Sentence, ICTR-2000-61-T, http://unictr.unmict.org/sites/unictr.org/files/case-documents/ictr-00-61/trial-judgements/en/110331.pdf, accessed 2 November 2016, para. 232.

${ }^{72}$ As was the case in Prosecutor v. Bemba, 21 March 2016, ICC, Trial Chamber III, Judgment pursuant to Article 74 of the Statute, ICC-01/05-01/08, https://www.icc-cpi.int/CourtRecords/CR2016_02238.PDF, accessed 2 November 2016.

${ }^{73}$ E.g. Ngirabatware, supra note 15.
} 
The benefit of the Bayes Net over Wigmorean analysis is that while the Wigmore chart does not attach any value or weight to the individual but related items of evidence that are pictorially represented, the Bayes Net expressly represents the probabilities of a variety of mutually conditional outcomes. ${ }^{74}$ There is perhaps a misconception that Bayesian probability generally is only relevant to those cases where the probability of a particular piece of evidence can be independently scientifically verified, as with a DNA profile. However, the method can also be used when subjective probabilities are involved. The application of Bayes' Theorem encourages fact-finders to interrogate the strength of their own confidence in the truth of a proposition.

It remains far from certain that judges and practitioners will be inclined to adopt formal methods, such as Wigmorean analysis and/or Bayes Nets, in their practice. Nevertheless, if a greater understanding of such methods were more widespread, this may give rise to a muchneeded debate in international criminal law on whether an atomistic or holistic approach to the evidence is deemed most suitable. Moreover, it would give rise to a long-overdue debate in international criminal law on the precise percentage of confidence in a finding that is required to meet the 'beyond reasonable doubt' standard. ${ }^{75}$ Furthermore, as the tribunals incorporate different standards of proof for different stages of proceedings, it would be valuable to attempt to quantify the level of confidence required for the standards of

\footnotetext{
${ }^{74}$ Franco Taroni, Alex Biedermann, Silvia Bozza, Paolo Garbolino and Colin Aitken, Bayesian Networks for Probabilistic Inference and Decision Analysis in Forensic Science (2nd edn., John Wiley and Sons, Chichester, 2014); Roberts and Aitken, supra note 63, 111.

${ }^{75}$ This is a debate that has been well-rehearsed amongst criminal law scholars in the United Kingdom and United States of America: see e.g. Jon O. Newman, 'Quantifying the Standard of Proof Beyond a Reasonable Doubt: A Comment on Three Comments' 5 Law, Probability and Risk (2006) 267-269, and Peter Tillers and Jonathan Gottfried, 'Case Comment: United States v. Copeland 369 F. Supp. 2 d 275 (E.D.N.Y. 2005): A Collateral Attack on the Legal Maxim That Proof Beyond Reasonable Doubt is Unquantifiable?' 5 Law, Probability and Risk (2006) 135-157.
} 
'reasonable grounds to believe',76 'substantial grounds to believe',77 and 'no case to answer', ${ }^{78}$ as well as 'beyond reasonable doubt'.

It must emphasised that these methods act as a tool for the illustration of the associations amongst items of evidence and propositions, and the strength of these associations (and, in the case of Bayes Nets, for the calculation of the probability of a proposition in light of the evidence at hand); the construction of a network is not a substitute for judicial reasoning, nor should it be. The exercises of determining which probabilities are conditional upon one another and allocating probabilities are fundamentally the task for the human decision-maker and, while new technology can assist with the calculations, it goes without saying that neither Bayes Nets nor Wigmore charts can act as a replacement to thinking. ${ }^{79}$

\section{Conclusion: Towards More Reliable Fact-Finding in International Criminal Trials}

This article argued that a clear divergence in international criminal judges' approach to factfinding has emerged in recent years. Some judges, who favour a more holistic approach to the evidence, have criticised their colleagues for taking an unduly 'fragmentary' approach to fact-finding, and vice versa. Having articulated this difference in approach, this article argued that a combination of features from both the atomistic and holistic styles is both achievable and favourable if the courts are to retain the legitimacy of their fact-finding authority.

The article noted some of the barriers to fact-finding that persist in the international criminal tribunals; aside from issues surrounding the quality of evidence, which have been well-

\footnotetext{
76 Article 58(1), ICC Statute. For an in-depth discussion, see Michael Ramsden and Cecilia Chung, "'Reasonable Grounds to Believe": An Unreasonably Unclear Evidentiary Threshold in the ICC Statute' 13(3) J. Int. Crim. Just. (2015) 555-577.

${ }^{77}$ Article 61(7), ICC Statute; see further, Klamberg, supra note 42, 147; Triestino Mariniello, 'Questioning the Standard of Proof: The Purpose of the ICC Confirmation of Charges Procedure' 13(3) J. Int. Crim. Just. (2015) 579-599.

${ }^{78}$ Rule 98bis, ICTY and ICTR RPE; Rule 98, SCSL RPE; Rule 167, STL RPE.

${ }^{79}$ McDermott, supra note 25, p. 510.
} 
documented by other authors, ${ }^{80}$ the quantity of evidence, procedural confusion on the proper role of the Trial Chamber in searching for the truth, and a lack of judicial collegiality can be pointed to in this regard.

In an era where states are withdrawing from the ICC ${ }^{81}$ there is a need now more than ever for international criminal judges to approach their fact-finding task with the utmost rigour, and to clearly link their ultimate conclusions to their evidential bases. Section 4 of this article discussed some formal methods that can be used in evidential analysis - namely Bayesian Networks and Wigmorean analysis - and their potential applicability in international criminal trials. It argued that an attempt to incorporate these methods would provide an opportunity for judicial reflection on what the standard of proof requires, and even if these formal methods are not widely used in every aspect of every case, an awareness of the principles underpinning them would be extremely valuable as an aid to thinking about structuring the evidence and interrogating the interrelationships between pieces of evidence and inferences that the court is asked to draw. From an academic perspective, because of the wealth of information available on their trials, including transcripts, interim decisions and full reasoned judgments, international criminal trials provide an ideal canvas for interdisciplinary collaboration between scholars from a broad range of disciplines (including law, mathematics, epistemology and philosophy) with an interest in fact-finding, in models for the analysis of evidence, and more broadly, in truth and justice.

Even if such formal methods are not considered or adopted in future international criminal law practice, there are reasons to believe that some of the barriers to fact-finding will not be as high in future practice. For one thing, we have just witnessed the first guilty plea before

\footnotetext{
${ }^{80}$ See e.g. Combs, supra note 8; Beth S. Lyons, 'Enough is Enough: the Illegitimacy of International Criminal Convictions', 13(3) Journal of Genocide Research (2011) 287-312.

81 Thierry Cruvellier, 'The ICC: Out of Africa', New York Times, 6 November 2016, http://www.nytimes.com/2016/11/07/opinion/the-icc-out-of-africa.html, accessed 6 November 2016.
} 
the ICC, ${ }^{82}$ and such pleas obviously make the court's role in fact-finding much more straightforward, even if the cathartic and truth-seeking aspects of a full trial might be missing. Secondly, the recent Bemba judgment and the significance of the FIDH's contemporaneous evidence highlights the increased role of NGOs in gathering evidence. At the time of some of the atrocities in the former Yugoslavia, Rwanda, Lebanon and Sierra Leone, there was little expectation that these events would appear before an international criminal tribunal some day, and still less knowledge on what sort of evidence might be useful for such trials. By today, a number of NGOs are developing technology that allows users to make videos and other contemporaneous records and store them securely for later access. With these developments, and if a clearer approach to the evaluation of evidence as suggested by this article were taken in the future, international criminal tribunals could base their judgments on much more than, in the words of Mirjan Damaška, 'a mere torso of actual wrongdoing', ${ }^{83}$ and thereby protect their legacies and the lasting impact of their judgments for many years to come.

\footnotetext{
${ }^{82}$ Prosecutor v. Al Mahdi, 27 September 2016, ICC, Trial Chamber VIII, Judgment and Sentence, ICC-01/1201/15, https://www.icc-cpi.int/CourtRecords/CR2016_07244.PDF, accessed 2 November 2016.

${ }^{83}$ Mirjan Damaška, The Faces of Justice and State Authority (Yale University Press, New Haven, CT, 1991), p. 112.
} 